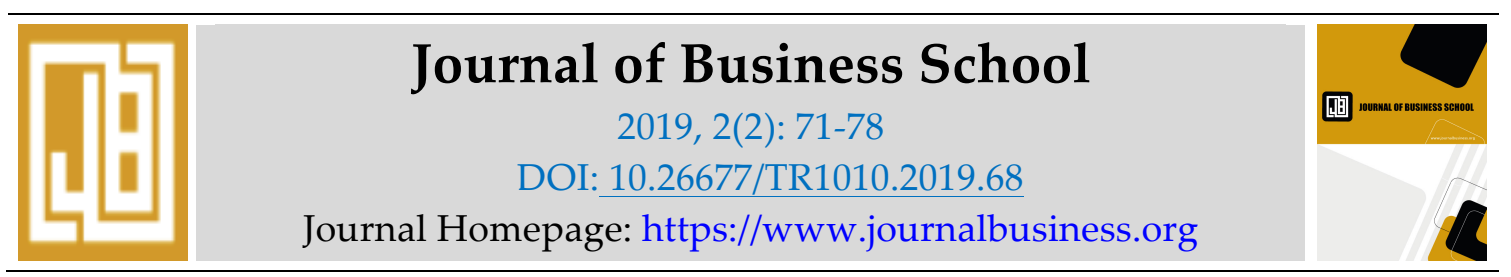

\title{
The Role of Money Supply in Economic Growth Enhancement: The Case Study of Nigeria
}

\author{
Cordelia Onyinyechi Omodero \\ Department of Accounting, College of Management Sciences, Michael Okpara \\ University of Agriculture Umudike, Umuahia, Abia State, Nigeria. \\ cordeliaomodero@yahoo.com.
}

\begin{abstract}
The study examines the role of money supply in boosting economic growth in Nigeria. The objective of the study is to establish the individual influences of money supply components on economic growth in Nigeria. The study employs data from 2009 to 2018 and uses Ordinary Least Squares regression technique for analysis of the data. The findings reveal that broad money supply (M2) has an insignificant negative influence on RGDP, while M3 and credit to private sectors (CPS) exert insignificant positive influence on RGDP. The study among others suggests that the Monetary Authority in the country should come up with monetary policies that will help drive the economy better and such policies should include reduction of interest rates on credits given to the private sectors. This measure will go a long way to expand private sector businesses and create jobs.
\end{abstract}

Keywords: Money supply, broad money, credit to private sectors, economic growth, Nigeria.

\section{Introduction}

Money supply is a monetary policy tool that is highly essential in boosting economic growth activities of a nation. Monetary policy is an important instrument used by Central Banks of countries to maintain economic stability and promote economic growth (Prasert, Kanchana, Chukiat \& Monekeo, 2015). Nnanna (2001) defines monetary policy as a tool at the disposal of the Monetary Authorities to influence the availability and cost of credit/money with the ultimate aim of achieving price stability. However, Monetary Authorities especially in the developing countries have a dual role of ensuring price stability and sustainable growth in an economy by employing instruments of monetary policy (Njimanted, Akume \& Mukete, 2016). On the other hand economic growth shows the percentage increase in GDP and is measured based on the fixed and the market prices

Money supply is a key factor that determines economic growth in an economy and has the capability of ensuring smooth running of economic activities in both public and private sectors. The private sector depends on money supply for availability of credits to carry on businesses, though at a price but not a choking interest rate. The monetarists believe that money supply is 
a tool that gives boost to economic growth based on unexpected increase in money stock (Jawaid, Qadri \& Ali, 2011) while the Keynesians argue that money supply has a limited influence on economic growth (Twinoburyo \& Odhiambo, 2017). Scholars such as (Chipote \& Palesa, 2014; Kamaan, 2014; Inam \& Ime, 2017) found that money supply exerts insignificant influence on economic growth thereby corroborating the Keynesian view. However, several other studies have established that money supply enhances economic growth of a nation (Nouri \& Samimi, 2011; Onyeiwu, 2012; Havi \& Enu, 2014Osasohan, 2014; Prasert et al., 2015; Mohamed Aslam, 2016) among others.

Based on the above background, the study seeks to investigate the role of money supply in enhancing economic growth in Nigeria between the periods from 2009 to 2018. The components of money supply in Nigeria this study employs to determine the real effect of money supply on economic growth in the country include: money supply (M2), money supply (M3) and credit to private sectors (CPS) while the economic growth is measured by the country's real GDP. M2 in Nigeria is the broad money supply which measures the total volume of money supply in the economy while M3 includes M2 in addition to long-term deposits. Credit to private sectors is the sum of money made available to private sectors for economic activities though at a price which is the interest rate.

RGDP N'BILLION

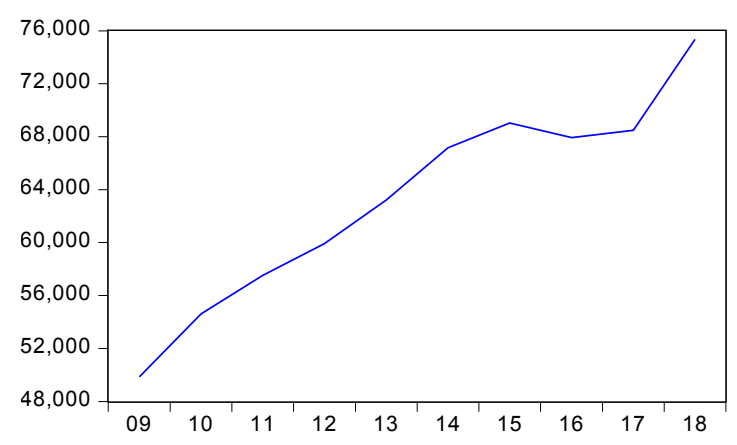

MSP(M3) N'BILLION

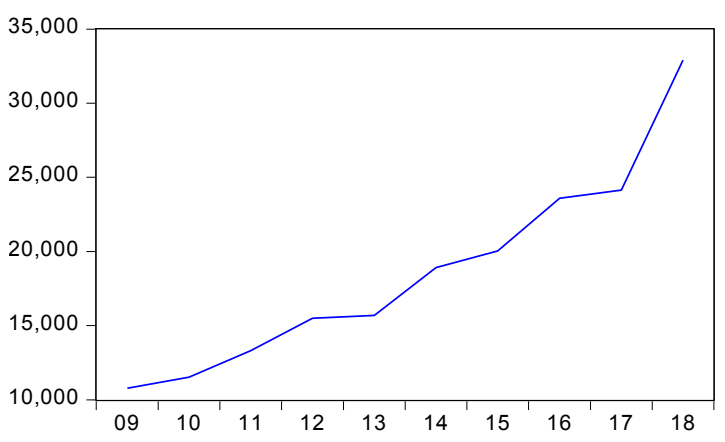

MSP(M2) N'BILLION
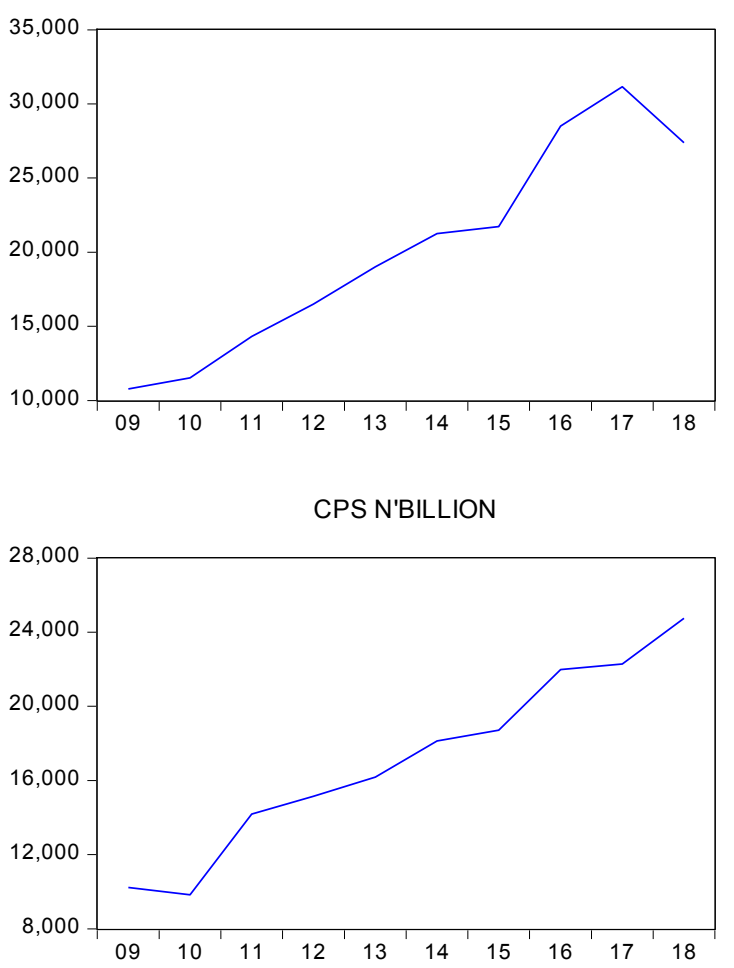

Figure 1: Trend of data collected from CBN website and Statistical bulletin, 2017 edition.

The figure 1 above shows the trends of money supply in Nigeria from 2009 to 2018 . The M3 and CPS have been on a steady growth with the RGDP but the M2 declined in 2018. This is attributed to so many economic factors which includes the prevailing socio-economic and political influences. However, M2 is the volume of money meant to circulate in the economy, the reduction in M2 is a way of controlling inflation since too much money in circulation in the economy gives rise to inflation. The Central Bank of Nigeria used the monetary policy tools to regulate the flow of money in the economy to the best interest of the country's economy. In order to maintain economic stability, money supply (M2) should be at the same rate with 
economic activities. The implication is that the demand for money should not exceed its supply, to avoid economic stagnation that could lead to recession.

\section{Theoretical review}

\subsection{The monetarist theory}

Friedman (1968) championed the monetarist theory which stresses that money supply is a key macroeconomic element that influences the growth of an economy. The monetarist theory states that variations in the money supply are the most important determinants of the rate of economic growth and the behavior of the business cycle (Kenton, 2018). Monetarism postulates that money supply is the major driver of economic growth which implies that as money supply increases, people demand more, factories produce more and new jobs are created (Kimberly, 2018). The proponents of this theory have argued that money has significant effect on price level in an economy in the long run while in the short run, it affects output and employment (Ahuja, 2011). The monetarists believe that the size of the money supply is more important than any other factor affecting the economy. They also have the belief that monetary policies are more effective than fiscal policies which comprise tools such government expenditure, debts and taxation. This belief is based on their understanding that Central Banks of nations are more influential than the government since they have the responsibility to control the money supply (Kimberly, 2018). According to Khabo (2002) there is a direct link between monetary sector and the real sector of the economy. The implication is that the Central Banks of nations can exert so much influence on economic growth rate since the monetary policy tools including money supply is under their control. Therefore, if a nation's money supply increases, economic activities will also increase and vice versa.

The monetarist theory formula is:

MV $\quad \mathrm{PQ}$

Where:

$\begin{array}{lll}\mathrm{M} & = & \text { Money Supply } \\ \mathrm{V} & = & \text { Velocity (number of times an average amount is spent per year) } \\ \mathrm{P} & = & \text { Price of goods and services } \\ \mathrm{Q} & = & \text { Quantity of goods and services }\end{array}$

\subsection{Liquidity preference theory}

Keynes (1936) propounded liquidity preference theory which states that the demand for money is not to borrow money but the desire to remain liquid, therefore, the price for the money is the interest rate. Liquidity preference theory combines money demand with the quantity of money supplied by the Central Bank to determine the money equilibrium level. According to John Maynard Keynes, the public holds money for three distinct reasons: firstly, for normal day to day transactions, secondly, as a precautionary measure and finally for speculative purposes which actually vary inversely with the rate of interest.

\section{Empirical review}

Jawad et al. (2011) applied co-integration and error correction model to examine the monetary fiscal trade policy and economic growth in Pakistan from 1981-2009 and found the existence of significant positive relationship between the variables both in the long and short run. The result specifically revealed that monetary policy is more effective than the fiscal policy in Pakistan. This finding confirms the Monetarists belief that monetary policy is a more effective economic policy than the fiscal policy. Nouri and Samimi (2011) used Levine and Renelt growth model to investigate the impact of monetary policy on economic growth in Iran from 1974-2008. The result from the Ordinary Least Squares (OLS) method revealed that money 
supply exerted a significant positive influence on economic growth in Iran. This study validates the Monetarist postulation that money supply is the key driver of economic growth in a country.

Senbet (2011) employed quarterly data from 1959 to 2010 to examine the relative impact of monetary and fiscal policies on the US real economic activity using Granger Causality tests and Vector Auto Regressive (VAR) models. The study found evidence that monetary policy influenced real output better than fiscal policy in the US economy. This study also substantiates the assertion of the Monetarists that monetary policy exerts better influences on economic growth than fiscal policy. Onyeiwu (2012) assessed the impact of monetary policy on economic growth in Nigeria from 1981-2008 using Ordinary Least Squares Method (OLS). The findings revealed that money supply had a positive impact on GDP. Chipote and Palesa (2014) employed Error Correction Model and Johansen Co-integration to examine the impact of monetary policy on economic growth in South Africa for a period of 2000 to 2010. The findings revealed that money supply as a monetary policy tool had insignificant influence on economic growth in South Africa.

Havi and Enu (2014) examined the relative importance of monetary policy and fiscal policy on economic growth in Ghana from 1980-2012. The study utilized Ordinary Least Squares (OLS) method which revealed that money supply had a significant positive impact on the economy of Ghana. Kamaan (2014) statistically assessed the effect of monetary policy on economic growth in Kenya and the study disclosed that monetary policy did not have a significant impact on economic growth in Kenya. Osasohan (2014) studied the impact of monetary policy on economic growth in the United Kingdom (UK) from 1940-2012 using Vector Error Correction Model (VECM). The study found that money supply and rate of inflation were the major tools of UK monetary policy that enhances economic growth in the country.

Prasert et al. (2015) employed Pooled Mean Group Estimator (PMGE) to investigate the association between money supply and economic growth of selected ASEAN Economic Cooperation (AEC) countries from 1995-2013. The selected countries were Cambodia, Indonesia, Lae PDR, Malaysia, Philippines, Singapore, Thailand and Vietnam. The findings revealed that money supply which comprises narrow money (M1) and demand deposit (DD) had positive relationship with economic growth measured by GDP. Mohamed Aslam (2016) investigated the impact of money supply on Sri Lankan economy from 1959-2013. The study made use of gross domestic product (GDP) as the dependent variable while the independent variables were money supply, exchange rate, export earnings, import outflows and the consumer price index. The regression results indicated that money supply maintained significant positive influence on economic growth at 1\% level of significance in Sri Lanka.

Njimanted et al. (2016) used Vector Auto-regression (VAR) method to analyze the effect of monetary policy tools on economic growth in the Central African Economic and Monetary Community (CEMAC). CEMAC was set up by a Treaty signed in 1972 by six states which include Cameroon, Chad, Equatorial Guinea, Gabon, The Central Africa and the Republic of Congo. The treaty was based on monetary co-operation arrangements in order to achieve price stability. The independent variables which were the monetary policy include money supply, interest and nflation rates. The study found that monetary policy tools affected the economic growth of the CEMAC community in diverse areas. Inam and Ime (2017) studied the impact of monetary policy on Nigeria's economic growth from 1970-2012 using Ordinary Least Squares (OLS) method and Granger Causality test. The study found an insignificant positive relationship between money supply and economic growth. 


\section{Methodology}

This study uses a causal research design whereby historical data are employed to examine the causal effect of the dependent variable on the independent variable. The dependent variable is the real gross domestic product (RGDP) while the independent variables include: broad money supply (M2), broad money supply (M3) and credit to private sectors (CPS) in Nigeria. All data were obtained from Central Bank of Nigeria (CBN) website and Statistical Bulletin, 2017 edition. The data collected covered a period from 2009 to 2018 and were analyzed using ordinary least squares technique with the aid of e-views version 9. All the data used were expressed in Billions of Naira.

The multiple regression model adopted for the study is:

$\begin{array}{ll}\text { RGDP }= & \beta 0+\beta_{1}(\mathrm{M} 2)+\beta_{2}(\mathrm{M} 3)+\beta_{3}(\mathrm{CPS})+\varepsilon \\ \text { Where, } & \\ \text { RGDP }= & \text { Real Gross Domestic Product } \\ \text { M2 }= & \text { Broad money supply (M2) } \\ \text { M3 }= & \text { Broad money supply (M3) } \\ \mathrm{CPS}= & \text { Credit to Private Sectors } \\ \beta_{0}= & \text { Constant } \\ \beta_{1-}-\beta_{3}= & \text { Regression Coefficients } \\ \varepsilon \quad= & \text { Error term } \\ \text { A Priori economic expectation: } \\ \beta_{1,} \beta_{2}, \beta_{3} & >\quad 0\end{array}$

The a priori economic expectation is that M2, M3 and CPS should be greater than zero indicating positive influence on RGDP.

\section{Data analysis and interpretations}

\subsection{Trend analysis of data}

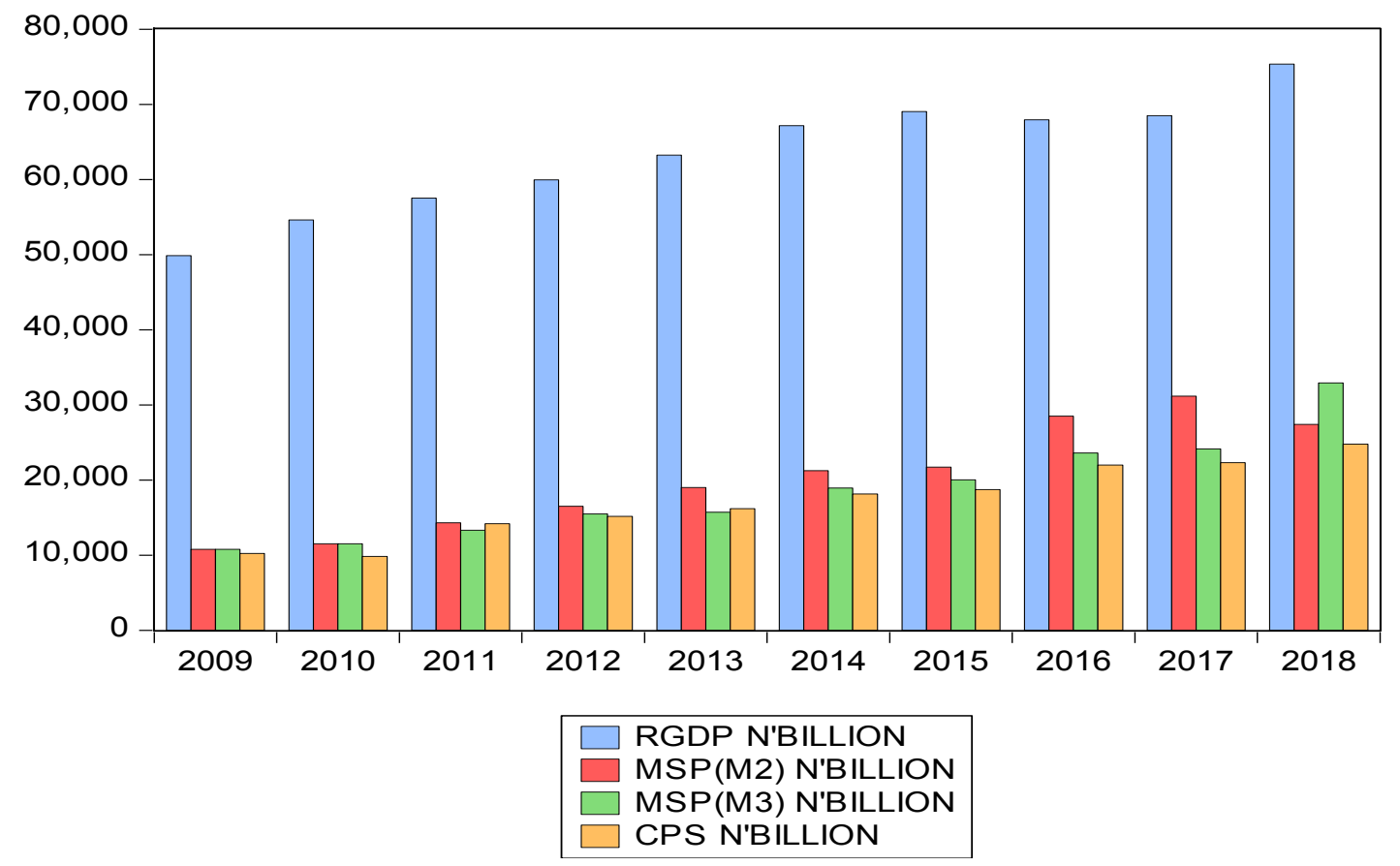

Figure 2: Trend of RGDP, M2, M3 and CPS

Source of Data: CBN website and Statistical Bulletin, 2017 edition 
Taking a closer observation on the figure 2 above, the money supply components do not seem to measure up with the RGDP. Although, from 2016 and up to 2018 there seems to be an improvement but the most important thing is that money supply in Nigeria should be adequate to drive economic growth as economically expected. The broad money supply commonly in circulation was at its peak in 2017 but declined again in 2018 while M3 took the lead. The growth in CPS is too slow, meanwhile it is necessary for the private sectors to have enough credit for business expansion that enhances economic growth in all ramifications.

\subsection{Table 1: Regression results}

\begin{tabular}{|c|c|c|c|c|}
\hline \multicolumn{4}{|c|}{ Dependent Variable: RGDP_N_BILLION } & \\
\hline \multicolumn{3}{|l|}{ Method: Least Squares } & & \\
\hline \multicolumn{4}{|l|}{ Date: 02/09/19 Time: $13: 21$} & \\
\hline \multicolumn{3}{|l|}{ Sample: 20092018} & & \\
\hline \multicolumn{3}{|l|}{ Included observations: 10} & & \\
\hline Variable & Coefficient & Std. Error & t-Statistic & Prob. \\
\hline MSP_M2_N_BILLION & -0.361567 & 0.494232 & -0.731572 & 0.4920 \\
\hline MSP_M3_N_BILLION & 0.041420 & 0.486517 & 0.085137 & 0.9349 \\
\hline CPS_N_BILLION & 1.916377 & 1.106148 & 1.732478 & 0.1339 \\
\hline $\mathrm{C}$ & 36986.54 & 4262.964 & 8.676249 & 0.0001 \\
\hline R-squared & 0.919286 & \multicolumn{2}{|c|}{ Mean dependent var } & 63306.70 \\
\hline Adjusted R-squared & 0.878928 & \multicolumn{2}{|c|}{ S.D. dependent var } & 7760.704 \\
\hline S.E. of regression & 2700.363 & \multicolumn{2}{|c|}{ Akaike info criterion } & 18.92933 \\
\hline Sum squared resid & 43751751 & \multicolumn{2}{|c|}{ Schwarz criterion } & 19.05037 \\
\hline Log likelihood & -90.64667 & \multicolumn{2}{|c|}{ Hannan-Quinn criter. } & 18.79656 \\
\hline F-statistic & 22.77874 & \multicolumn{2}{|c|}{ Durbin-Watson stat } & 2.003288 \\
\hline Prob(F-statistic) & 0.001115 & & & \\
\hline
\end{tabular}

Source: Author's computation, 2019.

The table 1 above shows the regression result of the study from e-views version 9 . The result shows a strong and positive correlation between money supply and economic growth represented by RGDP. The $R$ which is the correlation is $95.9 \%$ (that is the square root of $R^{2}$ ) while the R-squared is $91.9 \%$. The R-squared is the coefficient of determination which shows the extent to which all the independent variables explain the changes in the dependent variable. In this study, the independent variables explain about $91.9 \%$ of the variations in the dependent variable while $8.1 \%$ goes to other factors the model did not consider. The adjusted R-squared shows the calculated value of the independent variables captured in the model in order to increase the $R^{2}$. The Durbin-Watson statistic is approximately 2 which indicates absence of autocorrelation in the sample. The F-statistic is 22.77874 with the p-value of $0.001<0.05$. This result is statistically significant and shows that the model is appropriate for the study. In other words, the independent variables collectively influence economic growth in Nigeria positively and significantly.

However, the regression result on table 1 above also indicates the performance of the individual predictor variables and their level of influences on the response variable using the t-statistics. From table 1 above, M2 t-statistics is -0.731572 with the p-value of $0.49>0.05$ level of significance. This implies that M2 has an insignificant negative influence on RGDP. M3 t- 
statistics shows the value of 0.085137 with the p-value of $0.93>0.05$ level of significance. This result indicates that M3 has insignificant positive influence on RGDP. In the same manner, CPS $\mathrm{t}$-statistics is 1.732478 with the p-value of $0.13>0.05$ level of significance. This result also indicates that CPS does not have a significant positive impact on RGDP. These findings agree with the Keynesians who believe that money supply has limited influence on economic growth and also validates the studies of (Chipote \& Palesa, 2014; Kamaan, 2014; Inam \& Ime, 2017) who found that money supply exerts insignificant influence on economic growth. On the contrary, the findings contradicts the monetarists thinking that money supply determine economic growth as well as the studies of (Nouri \& Samimi, 2011; Onyeiwu, 2012; Havi \& Enu, 2014Osasohan, 2014; Prasert et al., 2015; Mohamed Aslam, 2016) who established that money supply enhances economic growth.

\section{Conclusion and recommendation}

Although the importance of money supply in an economy cannot be overestimated, however, its usefulness and effectiveness as a monetary policy tool depends on the country and the economic environment it is being applied. The Monetarists believe that monetary policy is better than the fiscal policy while the Keynesians argue that money supply has a limited effect on economic growth. This study has just contributed to the ongoing argument by establishing that money supply components jointly enhance economic growth (F-statistic result on table 1 above), while the individually (M2, M3 and CPS) none of them has significant influence economic growth. The broad money supply (M2) commonly used in circulating money in the economy exerts a negative influence though not significant while M3 and CPS put forth insignificant positive influence on economic growth.

Therefore, the study recommends that the Central Bank of Nigeria, should try to understand the role of money supply in enhancing economic growth and come up with monetary policies that will enable money supply to drive the economy properly in order to achieve economic growth. One of such policies is by reducing the price for credit to the private sectors because their activities contribute so much to economic growth in Nigeria. When the interest rates for obtaining credits are not choking the private sectors will invest more, thereby giving room for more outputs and job opportunities.

\section{References}

Ahuja, H. L. (2011). Macro-economic Theory and Policy. $7^{\text {th }}$ Revised Edition. S. Chand \& Company Ltd, New York.

Chipote, P. \& Palesa, M. (2014). Impact of monetary policy on economic growth: A case study

Of South Africa. Mediterranean Journal of Social Sciences, 5(15), 76-84. DOI: 10.5901/mjss.2014.v5n15p76.

Friedman, M. (1968). The role of monetary policy. The American Economic Review, 58(1), 1-17.

Havi, E.D.K. \& Enu, P. (2014). The effect of fiscal policy and monetary policy on Ghana'sEconomic growth: Which policy is more potent? International Journal of Empirical Finance, 3(2), 61-75.

Inam, U.S. \& Ime, B.S. (2017). Monetary policy and economic growth in Nigeria: Evidence from Nigeria. Advances in Social Sciences Research Journal, 4(6), 41-59. DOI: 10.14736/assrj.46.2806.

Jawaid, S.T., Quadri, F.S. \& Ali, N. (2011). Monetary-fiscal-trade policy and economic growth 
Pakistan: Time series empirical investigation. International Journal of Economics and Financial Issues, 1(3), 133-138.

Kamaan, C.K. (2014). The effect of monetary policy on economic growth in Kenya. International Journal of Business and Commerce, 3(8), 11-24.

Kenton, W. (2018). What is the monetarist theory? Available online at: https://www.investopedia.

Keynes, J.M. (1936). The General Theory of employment, interest and money. Palgrave Macmillan. Pages 472 (2007 edition).

Khabo, V.S. (2002). The impact of monetary policy of the economic growth of a small and open Economy: The case of South Africa. Department of Economics, University of Pretoria.

Kimberly, A. (2018). Monetarism explained with examples, role of Milton Friedman. Retrieved On 8/2/19 from https://www.thebalance.com/monetarism-and-how-it-works-3305866.

Mohamed Aslam, A.L. (2016). Impact of money supply on Sri Lankan Economy: An econometric

Analysis. International Letters of Social and Humanistic Sciences, 67, 11-17. Doi: 10.18052/www.scipress.com/ILSHS.67.11.

Njimanted, F.G., Akume, D. \& Mukete, E.M. (2016). The impact of key monetary variables on The economic growth of the CEMAC Zone. Expert Journal of Economics, 4(2), 54-67.

Nnanna, O.J. (2001). Monetary policy framework in Africa: The Nigeria experience.

South African Reserve Bank Conference. Available online at: https://www.resbank.co.za/lists/news\%20and\%20publications/attachmensts/57/nigeria.

Nouri, M. \& Samimi, A.J. (2011). The impact of monetary policy on economic growth in Iran. Middle-East Journal of Scientific Research, 9(6), 740-743.

Onyeiwu, C. (2012). Monetary policy and economic growth of Nigeria. Journal of Economics And Sustainable Development, 3(7), 62-71.

Osasohan, A. (2014). The impact of monetary policy on the economy of the United Kingdom: A Vector Error Correction Model (VECM). European Scientific Journal, 10(16), 19-42.

Prasert, C. Kanchana, C., Chukiat, C. \& Monekeo, K. (2015). Money supply influencing on Economic growth - wide phenomena of AEC open region. Procedia Economics and Finance 24(2015), 108-115. DOI: 1016/s2212-5671(15)00626-7.

Senbet, D. (2011). The relative impact of fiscal versus monetary actions on output: A VectorAutoregressive (VAR) Approach. Business and Economics Journal, Volume 2011:BET25, 1-11.

Twinoburyo, E.N. \& Odhiambo, N.M. (2017). Monetary policy and economic growth: A reviewOf International Literature. Journal of Central Banking Theory and Practice, 2, 123137. DOI: $10.2478 /$ jcbtp-2018-0015. 